\title{
Особенности геологического строения архейских диоритогнейсов участка «диоритовое окно» в пределах Мончегорского расслоенного комплекса (2.5 млрд. лет, Кольский регион)
}

Припачкин П.В., Рундквист Т.В.

ГИ КНЦРАH, Anamumbl, paul@geoksc.apatity.ru

Аннотация. В пределах палеопротерозойского Мончегорского ультрамафит-мафитового расслоенного комплекса (Кольский регион) локализован блок архейских пород разнообразного состава - диоритогнейсы, биотитовые, гранат-биотитовые и амфиболовые гнейсы и мигматиты вежетундровского комплекса. Изученные авторами структурные взаимоотношения пород (наличие жил, шлиров, будин, полосчатости, складок) говорят о сложной и многоэтапной истории формирования данного образования. Предполагается, что одной из причин интенсивной тектонической переработки пород архейского блока в районе так называемого «диоритового окна» могло послужить внедрение одной из фаз Мончегорского интрузивного комплекса. Для уточнения этапности образования магматических пород и степени их влияния на архейские диоритогнейсы, необходимы детальные структурно-геологические исследования. Кроме научного интереса, отлично обнаженный участок «диоритового окна» может рассматриваться в качестве дополнительного объекта геологических экскурсий в Мончегорском районе.

Ключевые слова: архейские диоритогнейсы, Мончегорский расслоенный комплекс, Кольский регион.

\section{Features of geological structure of Archaean diorite gneisses from the «diorite window» area in the Monchegorsk layered complex (2.5 Ga, Kola region)}

\author{
Pripachkin P.V., Rundkvist T.V. \\ GI FRC KSC RAS, Apatity, paul@geoksc.apatity.ru
}

\begin{abstract}
A block of Archaean rocks with various compositions (diorite, biotite, garnet-biotite and amphibole gneisses and migmatites of the Vezhetundrovsky complex) is located in the Paleoproterozoic Monchegorsk ultramaficmafic layered complex (Kola region). Structural interrelations between the rocks (the presence of veins, schlierens, boudins, bandings and folds) indicate a complex and multistage genesis of this formation. It is suggested that an intrusion of one of the Monchegorsk intrusive complex phases could be a reason for the intensive tectonic processing of Archaean rocks in the block near the so-called «diorite window». Detailed structural-geological study is required to specify stages of genesis of magmatic rocks and to evaluate their effect on Archaean diorite gneisses. The wellexposed area of the «diorite window» is not only an object of academic interest, but another site for geological excursions in the Monchegorsk area.
\end{abstract}

Key words: Archaean diorite gneisses, Monchegorsk layered complex, Kola region.

\section{Введение}

Мончегорский ультрамафит-мафитовый расслоенный комплекс (МРК) - уникальный геологический объект, расположенный в Мончегорском районе центральной части Кольского региона. Его уникальность проявлена как в прикладном, так и в фундаментальном смысле.

В первую очередь МРК известен как рудный объект с комплексной $\mathrm{Cu}-\mathrm{Ni}-Э П Г-\mathrm{Cr}-\mathrm{Fe}-\mathrm{Ti}-\mathrm{V}$ минерализацией. В Мончегорском районе насчитывается около сорока месторождений, рудопроявлений и пунктов минерализации медно-никелевых, платинометалльных, хромовых и железо-титанванадиевых руд, из которых примерно половина приурочена непосредственно к породам МРК. Общее количество никеля в МРК по приближенной оценке составляет 1700-1750 тыс. т, а платины и палладия - 451 т (Расслоенные интрузии..., 2004, Припачкин и др., 2013).

Интересен МРК и с геолого-петрологической точки зрения - для него характерна разнопорядковая магматическая (в том числе - ритмическая) расслоенность, наличие образований, подтверждающих многофазность его формирования, а также нескольких генетических типов рудной минерализации - контактового, жильного и рифового. 

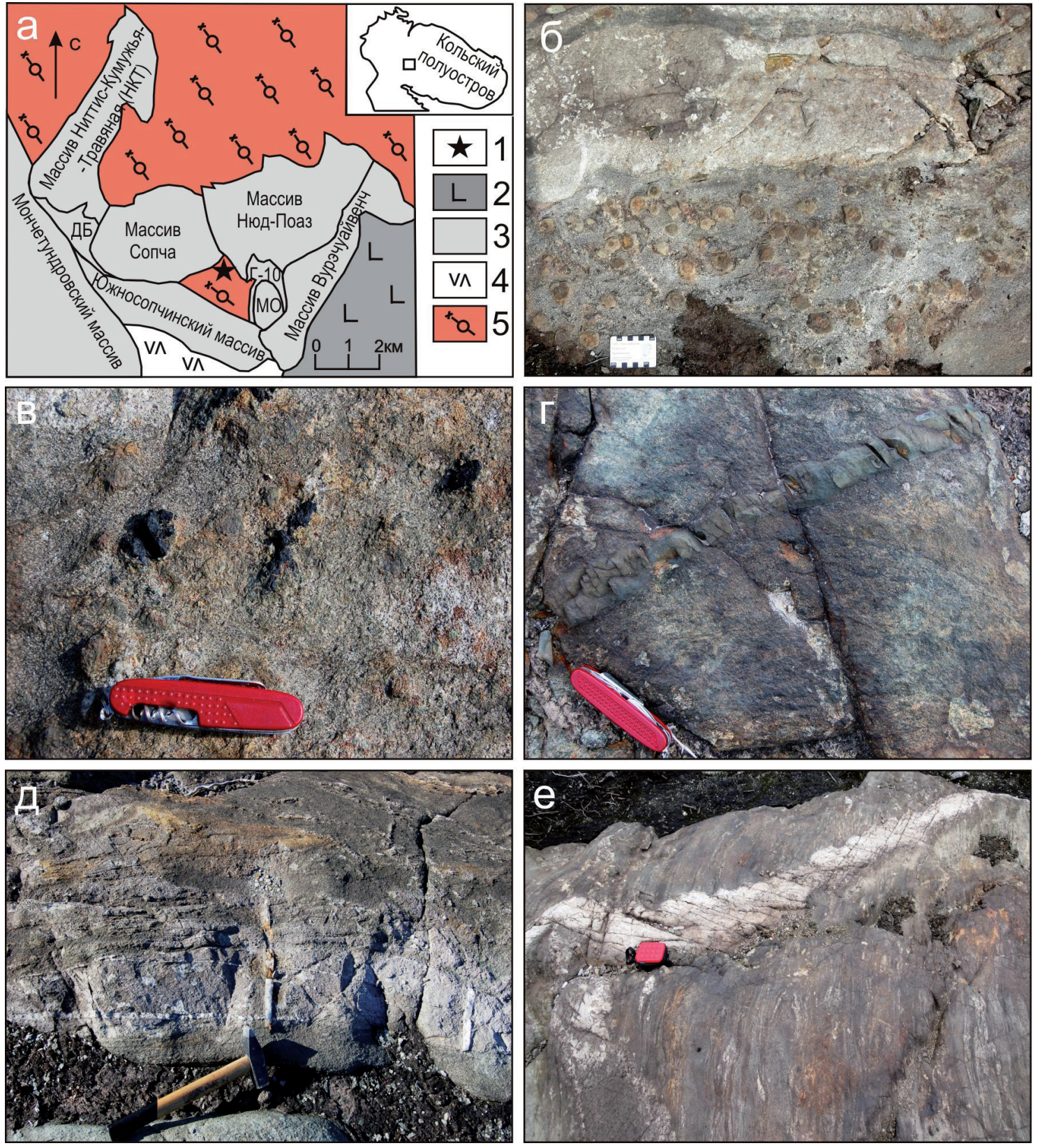

Рис. 1. Геологическая схема района и фото обнажений диоритогнейсов.

a - геологическая схема района Мончегорского комплекса; 1 - местоположение детального участка; 2 - раннепротерозойские вулканогенно-осадочные породы зоны Имандра-Варзуга; 3 - раннепротерозойские ультраосновные и основные породы Мончегорского комплекса и Мончетундровского массива; 4 - раннепротерозойские породы свиты Арваренч; 5 - архейские диоритогнейсы, метадиориты, гранат-биотитовые гнейсы; ДБ - дунитовый блок; Г-10 - массив габбро 10-ой аномалии; МО - блок Морошковое озеро. 6 - порфиробласты граната в диоритогнейсах; в - шлиры турмалина (черное) в диоритогнейсах; г - дайка метадолерита, пересекающая диортогнейсы; д,е. - кварцевые прожилки в диоритогнейсах. Длина ручки молотка 35 см, длина ножика и футляра 10 см.

Fig. 1. Geological scheme of the area and pictures of exposed diorite gneisses. a - geological scheme of the Monchegorsk complex area; 1 - location of the target area; 2 - early Proterozoic volcanogenic-sedimentary rocks of the Imandra-Varzuga area; 3 - early Proterozoic ultrabasic and basic rocks of the Monchegorsk complex and Monchetundra massif; 4 - early Proterozoic rocks of the Arvarench suite; 5 - Archaean granite gneisses, diorite gneisses, metadiorites, garnet-biotite gneisses; ДЬ - dunite block; $Г$-10 - gabbro massif of the 10th anomaly; MO - Moroshkovoye Ozero block. $\sigma$ - porphyroblasts of garnet in diorite gneisses; в - schlierens of tourmaline (black) in diorite gneisses; $\Gamma-$ metadoleritic dyke intersecting diorite gneisses; д,e - quartz veinlets in diorite gneisses. The length of the hammer handle is $35 \mathrm{~cm}$, the length of the knife and its case is $10 \mathrm{~cm}$. 

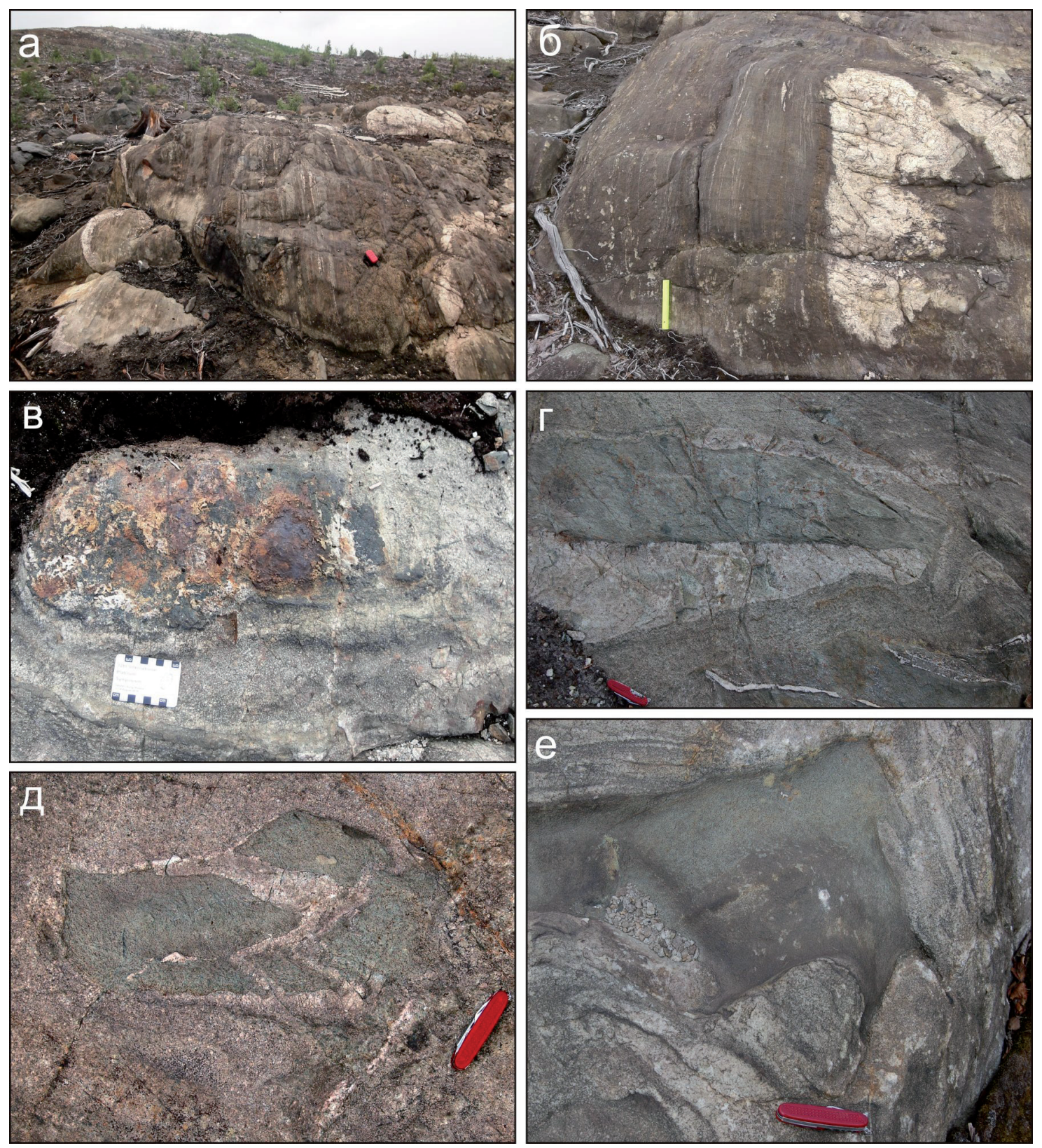

Рис. 2. Фото обнажений диоритогнейсов.

a - выходы полосчатых диоритогнейсов; б - e - будины различного состава и формы среди диоритогнейсов. Длина линейки 20 см, длина ножика и футляра 10 см.

Fig. 2. Picture of exposed diorite gneisses.

$\mathrm{a}$ - outcrops of banded diorite gneisses; $\boldsymbol{\sigma}-\mathrm{e}$ - boudins of varied compositions and forms among diorite gneisses. The length of the ruler is $20 \mathrm{~cm}$, the length of the knife and its case is $10 \mathrm{~cm}$.

В связи с изложенным, МРК привлекает к себе внимание отечественных и зарубежных специалистов и многие годы служит экскурсионной площадкой, в пределах которой демонстрируются особенности его геологического строения и рудного потенциала, проходят полевые части программ различных российских и международных геологических конференций. Однако, на наш взгляд, интересными для широкого круга геологов могут быть не только породы МРК, но и образования в зоне его непосредственного контакта.

Так, в северном и восточном обрамлении МРК залегают архейские породы ЦентральноКольского блока. Породы Центрально-Кольского блока представлены неоднократно и неоднородно метаморфизованными (от амфиболитовой до гранулитовой фации) парагнейсами и кристал- 
лическими сланцами кольской серии, и также ортопородами разного состава и происхождения. К последним относятся тоналит-трондъемитовые и эндербитовые гнейсы, чарнокито- и гранитогнейсы, рассматриваемые как вещество первичной сиалической коры. В единых структурах с тоналит-трондъемитовыми гнейсами залегают супракрустальные биотит-гиперстеновые, биотитгранатовые, гранат-кордиерит-силлиманитовые гнейсы, двупироксеновые кристаллические сланцы, железистые кварциты и другие породы кольской серии (Ранний докембрий..., 2005).

По данным А.М. Ремизовой с соавторами, непосредственно северо-восточное обрамление МРК сложено диоритами, гранодиоритами, биотитовыми, гранат-биотитовыми, амфиболовыми и высокоглиноземистыми гнейсами и мигматитами вежетундровского комплекса (Объяснительная записка..., 2007). Данные породы также развиты в депрессии между горами Сопчуайвенч и Нюдуайвенч, которые сложены преимущественно пироксенитами и норитами. Этот блок архейских пород в пределах палеопротерозойских пород МРК получил в литературе по геологии Мончегорского района название «архейского» или «диоритового окна». Авторами, в течение 2017-2018 гг. в пределах небольшого и прекрасно обнаженного участка «диоритового окна» у восточного подножия горы Нюдуайвенч (рис. 1) были проведены полевые исследования.

Результаты исследований

Согласно нашим данным, на изученном участке породы представлены преимущественно диоритогнейсами, для которых характерна полосчатость, сложная складчатость и будинаж. Наблюдается слоистое чередование массивных и интенсивно рассланцованных или полосчатых диоритогнейсов. На выветрелой поверхности рассланцованных диоритогнейсов хорошо видны протяженные шлиры крупных порфиробластов граната (рис. 1 б) различной формы и размера (до 2-3 см в поперечнике), а также скопления (гнезда, шлиры) черного турмалина (рис. 1 в).

Плагиоклаз-кварцевые жилы (рис. 1 д, е) пронизывают все породы обнажений, простирание жил северное, западное и северо-западное. Мощность жил - от первых сантиметров до десятков сантиметров, наблюдаемая протяженность - более 5 м. Также встречаются дайки метадолеритов мощностью от нескольких сантиметров (рис. 1 г) до первых метров.

Эффектные структуры будинажа можно видеть в обнажениях на северном склоне у подножия горы Нюдуайвенч, вдоль дороги к поселку Верхний Нюд. Здесь наблюдаются многочисленные будины различных по составу пород (рис. 2). Среди них встречаются метадолериты, гранатроговообманковые с магнетитом породы, массивные диоритогнейсы, существенно кварцевые породы и пр. Форма будин также весьма разнообразная. Встречаются будины овальной (рис. 2 в) или удлиненной (рис. 2 г) формы. В некоторых случаях будины отчетливо были разорваны и залечены тонкозернистым материалом (рис. 2 д). В других случаях возникает впечатление, что форма будины изменилась в ходе складчатости (рис. 2 е).

\section{Заключение}

Необычные структуры, зафиксированные нами в пределах «диоритового окна» среди магматических пород МРК указывают на сложную геологическую историю этого объекта и вызывают ряд вопросов. Например, пока до конца не ясно, сколько этапов деформаций претерпели породы на данном участке, сколько фаз складчатости здесь представлено, происходил ли будинаж одновременно со складчатостью или нет? Как известно, будинированные складки образуются при прогрессивной деформации, но для образования смятых в складки будин требуется две фазы деформации (Fossen, 2016). Так с какими именно геологическими событиями связан такой интенсивный будинаж в пределах «диоритового окна»? Возможно, одна из причин подобных тектонических преобразований - внедрение гигантского магматического тела - одного из массивов МРК? Очевидно, что на эти и другие вопросы невозможно ответить без специальных структурных исследований. Только подобные работы могут помочь оценить последовательность геологических событий как раннего докембрия, так, возможно, и более поздних.

Таким образом, расшифровка истории тектонической переработки пород на данном участке будет способствовать более точному пониманию историю формирования МРК и его отдельных ча- 
стей. Помимо научного значения, благодаря своей обнаженности и доступности, участок «диоритового окна» также может быть включен в число экскурсионных геологических объектов Мончегорского района.

Исследования выполнены в рамках темы НИР № 0226-2019-0053.

\section{Литература}

1. Объяснительная записка к Геологической карте Мурманской области. Масштаб 1:200000. Лист Q-36-III, IV. Под ред. А.М. Ремизовой. Апатиты. 2007. 121 с.

2. Припачкин П.В., Нерадовский Ю.Н., Федотов Ж.А., Нерович Л.И. Cu-Ni-ЭПГ и Cr месторождения Мончегорского района, Кольский п-ов, Россия. Путеводитель геологической экскурсии. Апатиты. Изд. Геологический институт КНЦ РАН. 2013. 44 с.

3. Ранний докембрий Балтийского щита. Под ред. В.А. Глебовицкого. СПб.: Наука. 2005. 711 с.

4. Расслоенные интрузии Мончегорского рудного района: петрология, оруденение, изотопия, глубинное строение. Ч. 1. Апатиты. Изд-во: КНЦ РАН. 2004. 177 с.

5. Fossen H. Structural Geology. Cambridge University Press. 2016. 510 p. 